\title{
The State as an Engine of Inclusive Sustainable Economic Growth and Development
}

\author{
Emmanuel Acquah-Sam, PhD \\ Wisconsin International University College, Ghana
}

Doi:10.19044/esj.2020.v16n22p177 URL:http://dx.doi.org/10.19044/esj.2020.v16n22p177

\begin{abstract}
This paper is a qualitative analysis of the critical role of government in promoting inclusive sustainable economic growth and development. This critical role of government transcends beyond an economy's experience of normal economic life or economic crisis, the type of economic system that is being practiced by a nation, and the level of development of a nation. The reason is that government serves as a stimulator, driver, sparker, lubricator, and the co-ordinator of the other economic units to create a conducive environment needed for private sector growth and the overall development of an economy. Though, the state also has its deficiencies in resource allocation and the management of the economy, a poorly functioning government portends economic doom. The exclusive roles of governments in promoting inclusive sustainable economic growth and development are: smoothening markets activities, promoting better macroeconomic performances, driving, sparking, stimulating, and lubricating the private sector for growth, mitigating social vices, undertaking financial sector cleanup, stabilisation, restructuring, providing stimulus packages to address economic meltdowns or recessions, and combating pandemics. This study concludes that the state serves as an engine of inclusive sustainable economic growth and development. This study recommends that governments must be held accountable by their citizenry and the international community for their actions and inactions and should be prevented from shirking their responsibilities to their societies. They need to be more efficient and proactive in ensuring public sector efficiency so as to spearhead economic growth and development. Again, the roles of the state and the private sector in promoting inclusive sustainable economic growth and development must not be mutually exclusive. Every economy must strive for a healthy balance between private sector and state planning that will lead to inclusive sustainable economic growth and development. Governments must promote effective governance and combat corruption both in the private and public sectors of every economy.
\end{abstract}


Keywords: Government, Private Sector, Inclusive, Sustainable, Growth, Development, Economic Systems

\section{Introduction}

Todaro \& Smith (2006, p.811) define economic growth as "The steady process by which the productive capacity of the economy is increased over time to bring about rising levels of national output and income". Economic growth means an increase in an economy's output of goods and services in a particular year relative to the previous year's output of goods and services. Economic development also refers to an improvement in quality of life of citizens emanating from several years of economic growth. Economic development is visualised from changes in the structure of an economy from an agrarian society to an industrialised and service led society, increased wealth, improved health, access to better education, good housing, access to drinking water, improved sanitation systems, increased life-expectancy, better foods, greater choices, more job opportunities, new technologies, and large scale infrastructural development. The International Economic Development Council's (IEDC) Economic Development Reference Guide mentions that no single definition suffices for all of the perceived different components of economic development (IEDC, 2000).

Economic history shows that countries have transitioned from underdevelopment to development as described by Walt Whitman Rostow. The economists of the 1950s and early 1960s viewed the processes of economic development as linear stages through which all countries must follow, given the appropriate amount and combination of saving, investment, and foreign aid. This economic growth path was a way of mimicking the historical development experiences of the more developed countries. As a result, economic development was akin to rapid aggregate economic growth. Development should be viewed as a multi-dimensional process involving the reorganisation and reorientation of entire economic and social systems (Todaro \& Smith, 2006). Economic growth and development must be inclusive and sustainable. The United Nations Development Programme (UNDP, 2017:p.4) defines inclusive growth as “... broadly shared prosperity resulting from economic growth." Inclusive economic growth must narrow inequalities in an economy. The Sustainable Development Goal Fund also reports that inclusive growth generates decent jobs, gives opportunities for all segments of society, especially the most disadvantaged, and distributes the gains from prosperity more equally to ensure that poverty and inequality are reduced (Inclusive Economic Growth for Poverty Eradication, n.d.). Also, sustainable growth and development means that present human societies must be able to meet their needs without compromising the ability of future 
generations to meet their own needs. It means that the present generation must use the environment and natural resources in a way that can preserve them for use by future generation. Mensah \& Casadevall (2019, p.1) write that "Sustainable development centres around inter-and intragenerational equity anchored essentially on three-dimensional distinct but interconnected pillars, namely the environment, economy, and society..." Inclusive and sustainable growth must help people to contribute to and benefit from economic growth with minimal impact on the environment. Samuels \& Djigma (2016: p.1) write that:

Delivering solutions for sustainable and inclusive growth and finance inherently reside at the country level. This requires explicitly building the technical operational processes for improving national enablingenvironments and capital markets (such as local expertise hubs) as well as the identification and development of investable entities -projects, instruments, and facilities -- that can successfully harness mobilize and secure private capital and ensure sustainable development impact.

Transforming the informal sector as an under-estimated and underrecognised driver of local economic growth can stimulate sustainable economic and inclusive growth in developing countries and small Island developing countries. The next section of this paper highlights some of the views expressed on the roles of the private sector and the public sector in inclusive sustainable economic growth and development.

\subsection{Private Sector versus Public Sector in Inclusive Sustainable Economic Growth and Development}

Various economic agents combine forces to contribute to inclusive sustainable economic growth and development. These economic agents can be broadly divided into the private sector and the public sector. The role of the private sector and that of the state in promoting inclusive sustainable economic growth and development continue to attract the attention of development economists, academics, policymakers, and the citizenry of nations of the world. Whereas some have touted the private sector as the engine of inclusive sustainable economic growth and development, many have also held contrary views. Spicer \& Bousquet (2019), Allison, Dewa, \& LeBlanc (2012), Samuels \& Djigma (2016), UK Aid (2011), and the World Bank (2004) write that the private sector serves as the engine of economic growth, because it creates jobs, increases trade, provides goods and services for the citizenry and generates tax revenue for government to finance basic public infrastructure. The African Development Bank Group (2011) examined the role of the private sector in Africa's economic development, and reported that the sector is Africa's engine 
of economic growth, because it accounts for over four-fifths of total production, two-thirds of total investment, and three-fourths of total credit to the economy, and employs $90 \%$ of the employed working age population. A vibrant private sector in which micro, small, and medium size enterprises thrive alongside large firms and labour intensive activities can also to achieve economic outcomes that lift greater numbers of people out of poverty requires. However, the sector is constrained by a legal and regulatory environment, and lack of access to infrastructure, finance, human capital and skills development, entrepreneurial development, and corporate governance.

There is the view that the actual economic unit that assumes the role of engine of inclusive sustainable growth and development is better assessed during periods of normal economic life and during periods of economic crisis (the state of the economy) as well as historical developments. For example, development in many industrial countries is said to have been shaped by their experience with the great depression, major wars, and the threat of communism (Tanzi, 1997:p.7, 8). Stiglitz \& Rosengard (2015) explain that since the 1980s, privatisation of state enterprises have been on the increase in Europe, but some of these privatised state institutions have failed to produce the expected results. Globally, the 2008 financial crisis caused the most significant increase in the role of government in economic growth and development in more than half a century, with governments taking over or providing substantial subsidies to the financial sector and many other industries. Dearden Nick, the director of UK campaigning organisation Global Justice, on Health Opinion on Aljazeera says that "It has been clear for more than 150 years that the free market creates substantial inequality and destruction even in the best of times. But when it comes to a crisis, reliance on the market can cause unimaginable devastation."

Furthermore, the role of the state or the private sector in economic growth and development is viewed to depend on the level of development of an economy - developed, underdeveloped, or developing (Tanzi, 1997, p.7,8; Spicer \& Bousquet, 2019; Utterwulghe, 2014, Samuels \& Djigma, 2016). The private sector is an engine for growth and stability in fragile countries. In countries affected by fragility, conflict and violence, the private sector plays a critical role in providing jobs and income (Spicer \& Bousquet, 2019). Hoedoafia, (2019) adds that the private sector has been identified as a key player in delivering inclusive sustainable economic growth and development in both developed, developing, and underdeveloped countries. It has been recognised as an avenue for achieving rapid industrialisation as well as poverty alleviation and other developmental goals in developing countries. Berhane (2012) investigated the experience of the East Asian countries of Japan, South Korea, and Taiwan and revealed that the three countries used government intervention mechanisms such as subsidised credit by targeting 
industries with high potential for productivity. Graceffo (2015, cited in Acquah-Sam, 2019) reveals that in China, majority of the 'national champion' companies are state-owned enterprises (SOE) which have grown in size and are among the largest companies globally. Obinyeluaku (2017, cited in Acquah-Sam, 2019) adds that the government of China developed a group of enterprises, called 'pillar industries', in automobile, machinery, electronics, petrochemical and construction sector, and invested directly toward these strategic areas. The presence of market failures, especially in developing countries where markets are weak or do not exist in some sectors has been argued to be the reason for sufficient role of the state in economic growth and development. Stiglitz \& Rosengard (2015) write that the precise nature of the role of the state in inclusive sustainable economic growth and development seems to differ: both between countries and within nations over time, from a society's expectations of its government's role in meeting the people's needs, and what the members of that society are willing to pay to meet these expectations (sometimes referred to as a 'social compact' or social contract'). For instance, governments of countries in northern Europe generally provide health, education, and social services and the citizens are willing to pay relatively higher taxes to finance them. However, such services are preferred by the citizens of the United States to be provided largely by the private sector in the United States.

These arguments have been extended to ask whether the state has any relevant role in economic activities at all. In the 1980s, the Neoclassical Counterrevolution development theorists argued that underdevelopment resulted from too much state participation in economic activities coupled with corruption, inefficiency, and lack of economic incentives (Todaro \& Smith, 2006). The Encyclopedia Britannica explains that the emergence of the neoclassical counterrevolution coincided with the withdrawal of developed countries from social democratic and Keynesian economic policies. Critics of the theory say that it was the cause of the spread of market-oriented interventions by the World Bank and International Monetary Fund (IMF) and efforts to synchronise global market activities regulated only by institutions reflecting the interests of transnational capital. Todaro \& Smith (2006) write that the neoclassical view of development was divided into three themes: the free-market approach, the public-choice approach, and the "market-friendly" approach. The free-market approach explains that markets alone are efficient in allocating scarce resources. Also, the public-choice theory says that governments can do nothing right. That is politicians, bureaucrats, citizens and states act solely from a self-interest perspective using their power and the authority of government for their own selfish ends. They conclude that minimal government role in economic activities is the best government. Furthermore, the market-friendly approach explains that governments do have 
a key role to play in facilitating the operation of markets through 'nonselective' interventions, through investing in physical and social infrastructure, healthcare facilities, educational institutions, and by providing a conducive environment for private sector growth. For instance, Peterson (1984) writing on the economic history of America argues that starting from the 19th century, most United States of America governments were reluctant to involve the Federal Government too heavily in private economic activities, except in the area of transportation. The role of the federal government was influenced by the concept of "laissez- faire". However, after sometime, owners of small businesses and farms, as well as labour movements began asking government to intervene.

Additionally, others have also asked whether the private sector or the state can impact inclusive sustainable growth and development in isolation. The Encyclopedia Britannica explains that the differences in rates of growth of economies are often attributed to government and entrepreneurship (private sector) which are not mutually exclusive. In the early stages of sustained growth, government has often provided the incentives (the development of transportation, power, water, financial inducements, subsidies, etc.) for entrepreneurial growth. In the 19th century, the main role of government in a developed capitalist system was seen to preserve law and order, defining private property rights, and giving business as much freedom as possible. However, the Great Depression of the 1930s caused many to believe that the laissez-faire system did not automatically provide the necessary incentives to the innovation and risk bearing essential for economic growth and at the very least, governments could undertake to prevent acute recessions. It is only through this that general business psychology (entrepreneurial skills) can be nurtured (Encyclopaedia, 2020). In Allison, Dewa, and LeBlanc (2012: p.19) report to the House of Commons, Canada, Bonnie Campbell, a professor in the Faculty of Political Science and Law at the Université du Québec à Montréal, is mentioned to have told the Committee that investigated the role of the private sector in international development that,

Investment in the private sector of itself does not translate into sustainable economic and social development. There is in fact no historical example anywhere on earth where sustainable growth, social and economic development, and poverty reduction took place through private investment in the absence of appropriate public policies and state interventions needed in order to plan, to regulate, and to monitor investment so that the presence of private investment would be harnessed to meet development objectives determined by the countries themselves. 
After independence, most African governments pursued state-led economic development strategies based on import substitution industrialisation. To manage this process, governments created large public administrations, while the private sector was marginalized. Unfortunately, this state-led economic development strategy proved to be unsustainable which resulted in the continent's real GDP growth averaging only $4.5 \%$ per annum over 1960-1980, with real per capita income growing on average by only $1.7 \%$ over the same period (African Development Bank Group, 2013).

\subsection{Rationale of Paper}

This paper, specifically, seeks to discuss the critical role of the state in promoting inclusive sustainable economic growth and development by serving as a stimulator, driver, sparker, and lubricator of the private sector, and the coordinator of the various economic units to create the enabling environment for private sector growth and development, and that there is the need for governments to be more efficient and proactive in ensuring public sector efficiency and in spearheading economic activities to promote overall inclusive sustainable growth and development in the economies of the world. It elucidates the arguments surrounding which particular sector of the economy holds the key to inclusive sustainable economic growth and development and encourages further research in the area.

\subsection{Resources Ownership, Control, Distribution, and Economic Management}

The differences in views expressed by development economists, academics, policymakers, and the citizenry about the actual roles of the state and the private sector in economic growth and development have contributed to the extent to which resources are owned and distributed, and how countries have been organised and managed overtime. The problem of how to allocate societies' scarce resources efficiently among virtually unlimited wants of individuals, firms, governments, and societies in general results in the quest for answers to the following questions:

- What kind of goods and services should we produce?

- How do we produce the goods and services?

- For whom do we produce the goods and services?

- When do we produce the goods and services?

- Where do we produce the goods and services?

The answers to the above questions have been provided by the various types of economic systems that have been practiced by countries overtime. An economic system refers to the ownership, control, and distribution of economic resources in an economy. Economists identify three main types of 
economic systems: socialism (command economic system), capitalism (free market system), and mixed economic system (the combined efforts of the private sector and the state in ownership and allocation of economic resources in an economy).

In a socialist system, the state owns the key resources in an economy. A central planning body that is formed by the state decides the means of production and distributes the resources that are virtually owned by the state to maximise the welfare of the citizenry. On the other hand, in a capitalist economic system also called free market economy or free enterprise economic system, most means of production are privately owned and production and income distribution are mostly done by individual resource owners. Individual resource owners (the private sector) allocate the scarce resources among the competing wants of society through the price mechanism. Thus, consumers and producers desires are co-ordinated through the payment and receipt of prices for the goods and services produced and consumed. Governments mainly provide law and order, and property rights to guide the actions of the people. Furthermore, in a mixed economic system, resource ownership and allocation are done by both the state and the private sector either separately or through private-public partnerships. All these economic systems seek the ultimate goal of ensuring efficient allocation of scarce resources in an economy to maximise social welfare and economic growth and development. Experience has shown that in the short run, both the command economic system, the free market system, and the mixed economic system enjoy some advantages, but in the long-run, they fail to maximise the overall welfare of the members of the societies that practice them.

Today, the collapse of pure capitalism such as was practised in Mexico and pure socialism such as was practiced by the Soviet Union and the adoption of mixed economic system by many nations of the world have resulted in the argument as to which economic unit is the engine of inclusive sustainable economic growth and development and the right balance between market and state planning that promotes inclusive sustainable economic growth and development.

\subsection{Benefits of Combined Efforts of State and Markets in Economic Development}

Proponents of mixed economic system are of the view that the system rewards individuals for their ingenuity through profits which accrue to them from the sale of their inventions or innovations that result from process innovations and products innovations with the creation of a conducive environment for private sector growth by government.

Additionally, the mixed economic system ensures rapid growth and development of an economy through healthy competition among business 
firms which leads to the production of numerous and quality goods and services by business firms. Its effect is wealth creation and maximisation of shareholders' value through appropriate regulatory measures by government.

Furthermore, the mixed economic system has inherent mechanisms through which the imbalances within markets are corrected. This is done through price adjustments to excess demand for goods and services or excess supply of goods and services. Government intervenes to correct inefficiencies of competition and exchange. On the basis of this, the system responds favourably to changes in both domestic and world macroeconomic variables such as changes in crude oil prices, exchange rates, trade deficits, and interest rates. Thus, a mixed economy allows private and state participation in production, while the government in addition, ensures that society is protected from the negative effects of market activities. Governments provide security to sellers and buyers. This security helps maintain a stable market.

Mixed economies allow more freedom than command economies and pure capitalist economies, such as the freedom to possess the means of production, to participate in managerial decisions; and to buy and sell. Mixed economies have a high level of state participation and spending, leading to taxfunded infrastructural facilities such as schools, hospitals, roads, ports, harbors, water, and electricity, etc. Restrictions such as environmental regulation, labour regulation, antitrust, and intellectual property rights are put on businesses for better standards of living.

There is less income inequality in mixed economies since governments always attempt to bridge the gap between the rich and the poor in society by determining minimum wages and appropriate income tax policies. The next issue to be examined is the exclusive role of government in inclusive sustainable economic growth and development.

\subsection{Theoretical Review}

The Roy Forbes Harrod and Evsey David Domar (Horrad-Domar) model of economic growth is expressed simply as $\frac{\Delta \mathrm{Y}}{\mathrm{Y}}=\frac{\mathrm{s}}{\mathrm{k}}$, where $\frac{\Delta \mathrm{Y}}{\mathrm{Y}}$ is the rate of economic growth (GDP; $\mathrm{s}$, is saving ratio, and $\mathrm{k}$ is capital-output ratio. Horrad (1936) and Domar (1957) explained that in the absence of government, the growth rate of an economy's output of goods and services will be directly or positively related to the savings ratio, s, (the proportion of any additional income that is saved). The positive relationship between saving ratio and output growth means that the more an economy's citizens save and invest out of a given gross domestic product (GDP), the faster the growth of that economy will be. Also, they explained the inverse or negative relationship between an economy's capital-output ratio, $\mathrm{k}$, and output growth that the higher $\mathrm{k}$ is, the lower the rate of growth of output will be. This means that 
more capital stock will be used to produce a given level of output (depicting inefficiency in capital use). Therefore, a lower $\mathrm{k}$ symbolises higher efficiency in the use of capital stock in producing a given level of output. In conclusion, for an economy to grow rapidly, it must save and invest a certain proportion of its national income annually. The more economies can save and invest, the faster they can grow (Todaro \& Smith, 2006). The model seems to place much emphasis on the role of the private sector in economic growth and development. However, Screpanti \& Zamagni (2005, pp.245) write that “... Harrod has always refused to recognise his model as a realistic description of the actual dynamics of a capitalist economy, a dynamic which is considered as basically characterised by continual cyclical fluctuations."

In the eighteenth century, French economists argued that economic growth and development resided in international trade and advocated the active promotion of trade and industry (mercantilism). Mercantilism maximised exports and minimised imports for an economy thereby reducing current account deficit or increased current account surplus. It was partly in response to the mercantilists' view that Adam Smith in his book, The Wealth of Nations (1776), argued for a limited role for government in economic activities. Adam Smith explained that competition and the profit motive of firms would lead individuals to pursue their own private interests and in the end serve the public interest of promoting economic growth and development. Only firms that produce what society wants and at relatively low prices will survive. Adam Smith explained that the economy is controlled by an invisible hand (inherent mechanism) to correct the imbalances in the economy. Furthermore, many of the most important nineteenth-century economists, such as John Stuart Mill and Nassau Senior, developed the doctrine of laissez faire, arguing that government should not interfere with private sector activities or resist the attempt to regulate or control private enterprises so that society can gain the maximum benefits from the activities of the private sector. However, Karl Marx, Jean Charles Léonard de Sismondi, and Robert Owen, and others are said to have attributed the evils in society to the private ownership of capital. Karl Marx was the most influential among those who advocated a greater role for the state in controlling the means of production. Others, like Robert Owen, saw the solution to economic growth problems neither in the state nor in private enterprises, but in smaller groups of individuals getting together and acting co-operatively for their mutual interest (Stiglitz \& Rosengard, 2015).

Keynes (1936, cited in Berhane, 2012) was of the view that the appropriate role for the state in economic growth and development, is not the ownership of means of production, but to determine the aggregate amount of resource devoted to augmenting the instruments and basic rate of rewards to those who own them. Screpanti \& Zamagni (2005) explain further that 
"Keynes observed that there are spheres of activity in which private initiative carries out an essential economic role and in which the State should not interfere, while there are also spheres of activity in which the State operates in a better way than the private sector. He did not go very far forward in identifying the latter types of economic activity, which, basically he reduced to two: credit control and the regulation of the process of formation and allocation of savings. He put forward the idea that the State should take on the role of 'concerted and deliberate management' of the economy, albeit by means of a limited number of political instruments."

The views expressed above point out that both the state and the private sector contribute to economic growth and development, but fail to conclude on the precise role or the extent of each sector's contribution to inclusive sustainable economic growth and development as well as which sector serves as the engine of inclusive sustainable economic growth and development. This paper fills the gap by elucidating the arguments surrounding which particular sector of the economy holds the key to inclusive sustainable economic growth and development and encourages further research in the area. The next section provides a conceptual framework on the leading role of the state in promoting inclusive sustainable economic growth and development.

\subsection{Conceptual Framework}

This paper conceptualises the role of governments in promoting growth in the private sector and the overall inclusive sustainable economic growth and development of an economy in Figure 1. In Figure 1, the paper explain that governments impact private sector economic activities in the primary sector, secondary sector, and the tertiary sector of an economy and their eventual contributions to inclusive sustainable economic growth and development through the formulation and implementation of fiscal, monetary, and industrial policies. Abu-Bader \& Abu-Qarn (cited in Alinska, Filipiak, \& Kosztowniak, 2018) show that public sector actions based on appropriate programmes and financed from government's budget could have a positive impact on GDP. The reasons are: firstly, the state provides pure public goods (electricity, roads, bridges, stadia, parks, etc.); secondly, the state may own or manage enterprises and institutions and produce goods and services; thirdly, the state regulates property rights and improves the efficient allocation of resources in case of externalities; in addition, the state's income taxes and transfer payments affect income distribution and can create a fairer society. Lastly, the state often facilitates the functioning of markets by dealing with asymmetric and imperfect information. 
Figure 1: Conceptual Framework of Governments' Role in Promoting Economic Growth and Development

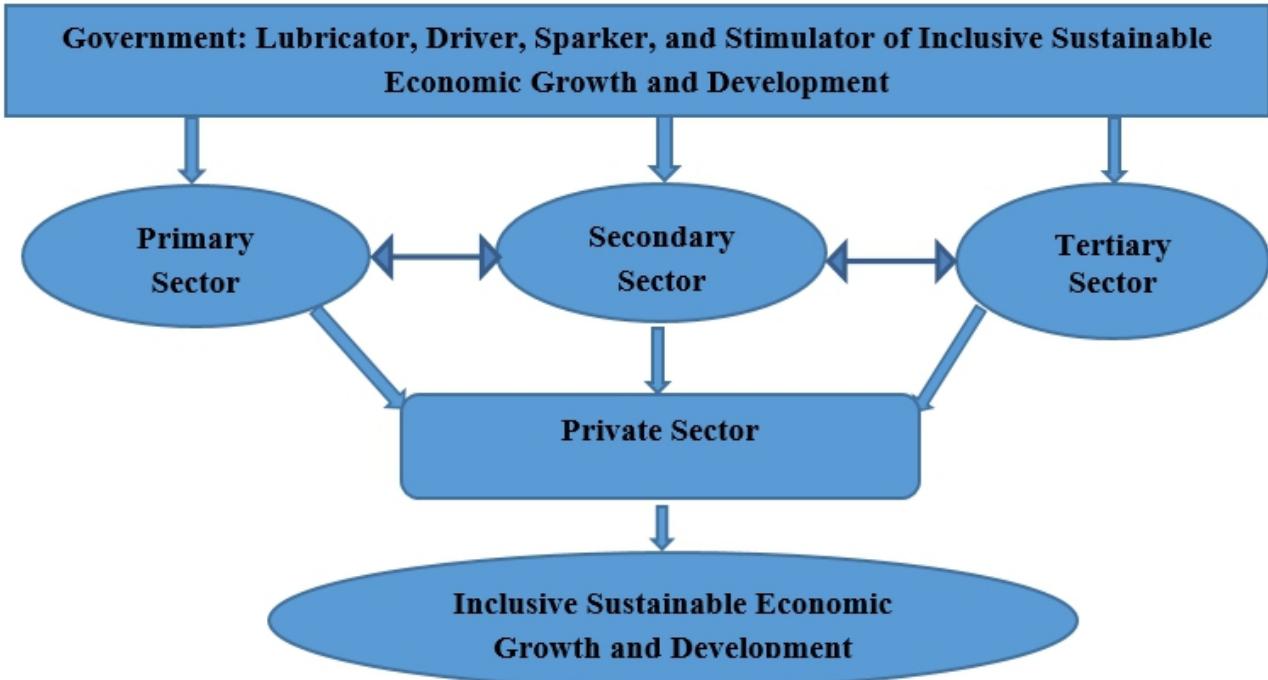

Source: Author's Own Construct, 2020

The arrows show how each economic unit impacts on the other (s) to achieve economic goals. The arrows that link the government sector to the primary, secondary, and tertiary sectors show that governments directly produce goods and services for domestic and foreign users, provide law and order, define property rights, embark on large scale infrastructural development, formulate and implement credible national policies, address financial sector instabilities and crises, markets failures, and manage economic recessions and global pandemics through the offering of stimulus packages to private sector enterprises and individuals to promote the growth of the three sectors. According to Stiglitz \& Rosengard (2015), government alters private sector activities through a variety of regulations, taxes, and subsidies.

The arrows connecting the primary sector, secondary sector, and tertiary sector show the interrelations among the three sectors in promoting inclusive sustainable economic growth and development. The primary sector includes all the economic activities which are connected with extraction and production of natural resources such as agriculture, fishing, mining, etc. Also, the secondary sector or the industrial sector is concerned with all activities involving the processing of already extracted primary materials (construction and manufacturing). It provides finished goods and services to satisfy the needs of people. Furthermore, the tertiary sector or the service sector is concerned with providing support services to the primary and secondary sectors in an economy such as education, information communication technology, transport, banking, insurance, warehousing, advertising, etc. 
Private sector activities in the three sectors contribute to the growth of the entire private sector.

\subsection{Exclusivities of Governments' Roles in Inclusive Sustainable Economic Growth and Development}

Governments play many roles in their respective economies to propel inclusive sustainable economic growth and development. The exclusive role of governments in promoting inclusive sustainable economic growth and development are: smoothening markets activities, promoting better macroeconomic performances, driving, sparking, stimulating, and lubricating the private sector for growth, mitigating social vices, undertaking financial sector cleanup, stabilising, restructuring, and providing stimulus packages to address economic meltdowns or recessions; and fighting pandemics. These exclusive roles are explained as follows:

- Smoothening markets activities: Governments generally work to smoothen the workings of the economy in areas where the private sector (markets) fails to play its role efficiently in resource allocation and promotion of economic growth. The existence of monopoly power, externalities, information asymmetry, and public goods cause markets to fail in allocating resources efficiently. Governments, therefore, tackle these sources of market failures through the introduction of taxes, laws, regulations, pollution permits, and government campaigns to change people's preferences to address negative externalities and monopoly power. Also, subsidies are paid to producers who generate positive externalities. Governments charge road tolls and facilities user fees to address the problems of free riding and congestion emanating from the use of public goods and services. They direct market players to provide relevant information for effective exchange of goods and services among producers and consumers to address the problem of information asymmetry. According to Reed (2015), in Germany, the government pays rent allowance to about 54.1 per cent of most households who are renters. For example, in 2012 the German government paid housing allowance to about 783,000 households. In Singapore there is a high level of government intervention in the housing market, providing about 80 per cent of all housing in the country. Also, there are grants for first time home buyers and second time home buyers in Singapore. The Office of Fair Trading (2009) in Great Britain reports that in 2002, the government regulator for gas and electricity markets in Great Britain, Ofgem, imposed a penalty of $£ 2$ million on London Electricity for breaching selling regulations. 
- Promoting better macroeconomic performances: Macroeconomic policies are used by governments and other policy makers to improve economic performance and well-being. Macroeconomic objectives of governments are intended to promote economic growth and stability, control inflation, long term low interest rate, increased employment opportunities, financial inclusion, favourable balance of payment and terms of trade, equitable distribution of income and wealth, providing incentives for capital accumulation and investments, and employment growth through the formulation and implementation of appropriate fiscal, monetary policies, and industrial policies as well as supervision of private sector activities. For example, during the Great Depression of 1929 in the United States of America, President Franklin D. Roosevelt and other policymakers created the Federal Deposit Insurance Corporation (FDIC) and the Securities and Exchange Commission (SEC) to protect banking deposits and regulate stock market trading. Government spending also increased at the beginning of World War II, and these changing conditions helped reverse the economic depression of the previous years. Also, in the early 1980s, President Ronald Reagan's tax cuts and increased military spending stimulated the American economy for growth (Investopedia, 2015). Furthermore, as a means of reducing the problems of unemployment in Ghana, the government of Ghana, through the Nation Builders Corps (NABCO) programme initiated in November, 2018 provided employment for about 100,000 young unemployed tertiary graduates across seven modules of the scheme namely, Educate Ghana, Heal Ghana, Feed Ghana, Revenue Ghana, Civic Ghana, Digitise Ghana, and Enterprise Ghana (Ministry of Finance 2019). Additionally, the government of Ghana has injected over $\$ 269 \mathrm{~m}$ worth of agricultural equipment such as heavy duty tractors, multi-crop threshers, maize shellers, mechanical planters, cereal harvesters, motorized sprayers, and hand-held tractors into the agricultural sector in Ghana since 2017 to mechanise agriculture in the country. These equipment were for commercial and smallholder farmers for sale at $40 \%$ discount (KaleDery, 2020).

- Driving, sparking, stimulating, and lubricating the private sector for growth: UK Aid (2011) explains that, the private sector is more than just the engine of growth... By creating job opportunities, providing new goods and services including financial services to the people and by paying taxes, it contributes immensely to the society. Its ability to innovate and do things more efficiently allows societies to achieve more with the resources at their disposal. There is no one recipe for 
growth, but getting investment levels up matters and getting the environment right for the private international and domestic sector to invest and thrive is crucial. Though it highlights how the private sector serves as the engine of economic growth, but it concludes that whatever the private sector can do depends on the provision of an enabling environment for growth and this is provide by the state. Rodriguez (2019) explains that private sector engagement is about governments and other public sector actors collaborating to improve the security, governance, and economic environment that enables investment, job creation, and widespread prosperity. A state with its numerous institutions is like a big tree with many branches. The state functions like a tree and the numerous private sector business firms function like the branches of the tree. The survival of the branches (private sector firms) depends on the health of the tree in supplying water and nutrients to the branches (the private sector firms). Since fiscal policies, monetary policies, and industrial policies, as well as basic and major infrastructural facilities are provided by the state to ensure efficient running of an economy, the state serves as a driver, sparker, and lubricator, and stimulator of the private sector for economic growth and development. Though, the state also has its deficiencies in resource allocation and the management of the economy, a poorly functioning government portends an economic doom. It must also be borne in mind that, bad government policies and poor supervision of the private sector's activities may cripple an entire economy. For example, the government of Ghana, under the Food Crop Production module, provided subsidies in the form of $12,000 \mathrm{mt}$ of organic, $821,778 \mathrm{mt}$ of blended inorganic fertilizers, and 24,000mt of improved seeds valued at GHS0.6 billion to about 1.9 million farmers. Furthermore, 2,700 extension officers were recruited and that improved the Extension Agent Farmer ratio from 1:1908 to 1:706. All of these were done between 2017 and 2018. Additionally, to ensure safe launching and landing of artisanal fishing and to create and maintain hygienic environments as well as create potential job opportunities within the fishing communities, construction of eleven (11) coastal fish landing sites at Axim, Dixcove, Elmina, Moree, Mumford, Winneba, Senya Beraku, Fete, Teshie, Keta and Jamestown in Ghana had commenced in 2019. Furthermore, the National Entrepreneurship and Innovation Programme (NEIP) trained 12,000 young entrepreneurs who were drawn from the 16 regions in modern business practices to improve their capacity and to make their products competitive at the global level. Financial support was given to 3,000 of the trainees. Financial support was also provided to 100 disabled 
women entrepreneurs to improve their businesses. It was also budgeted that in 2020, another set of 15,000 entrepreneurs would be trained out of which 4,000 would be financially supported under the Presidential Business Support Programme (Ministry of Finance, 2019).

- Mitigating social vices: The free market system worsens the plight of the poor or the vulnerable in society, because the culture of "weism", whereby each person is another's keeper is lost on the people. Some citizens become self-centered (egoists) and attempt to maximise their satisfaction or wealth at the expense of others. Although hard work among the citizenry of a nation is encouraged, it must be emphasised that nation building is not always about wealth creation, but also about how the wealth is created and its net effect on society. Amassing wealth does not necessarily lead to happiness, peace, security, and contentment. The inability to meet these needs has contributed to the spate of social vices such as drug abuse, prostitution, gigolo, internet frauds, burglary, armed robbery, etc. Most of those who engage in these evil acts feel that they have been given a raw deal in life and that they target the well-to-do in society and rob them of their riches, maim and kill them. Others, in an attempt to have places to sleep and survive, have built slums that have become hubs of criminal activities. People build houses on water courses which cause perennial floods in major cities. All these have put a strain on governments' budgets as attempts are made to mitigate them. The greed associated with the free market system (the desire to amass wealth by individuals) will continue to pose a threat to the global world as suggested by former Chief of the Federal Reserve, Alan Greenspan (Thursday, September 10, 2009 edition of the Daily Graphic). According to the September 5, 2009 edition of the IMFSurvey Magazine, the Head of the IMF, Diminique Strauss-Kahn, told reporters after the G-20 London meeting that, "We are seeing the third wave of the crisis, which is rising levels of unemployment". Supposedly, the first two waves were the financial crisis and the consequent global economic crisis. Governments, therefore, were advised to continue with economic stimulus plans to combat the crisis, though signs of recovery could be seen. Ojeleye (2017) a visiting don from the Nigerian Baptist Theological Seminary called on African leaders to head-on tackle the challenge of materialism, because had been responsible for the widespread social vices plaguing the continent. Governments have setup livelihood empowerment programmes (LEAP), national disaster management organisations to tackle disasters which are both natural and artificial in nature, mental and rehabilitation centres are built and the security 
employed to fight crime in the society. Mohammed, Bukari, Issahaku, \& Mohammed (2019) assessed the contribution of the livelihood empowerment against poverty (LEAP) programme in reducing rural poverty in the Karaga district of Northern Ghana, and concluded that the programme is contributing to poverty reduction among the poor. The Bible states categorically that, the love of money is the root of all manner of evil. Many in their quest for too much money have brought a lot of pain to themselves (I Timothy 6:10). We should remember that godliness with contentment is great gain. We brought nothing into the world, and it is certain that we can carry nothing out of the world (I Timothy 6: 6-7).

- Undertaking financial sector cleanup, stabilisation, restructuring, and providing stimulus packages to address economic meltdowns or recessions: Financial instability and crisis, and global economic recessions with their adverse effects on both developed and developing nations have been caused by the activities of business firms and consumers in markets. For instance between 2006 and 2008 many economies of the world led by the United States of America experienced financial crunch. In 2008/9, to save economies from the catastrophic effects of credit crunches and its associated economic recessions, various forms of stimulus packages were introduced by governments of affected countries. The United States of America (U.S.A.), under Ex-President George Walker Bush, in 2008 introduced the Emergency Economic Stabilization Act to bail out the U.S. financial system from financial distress. This law authorised the United States Secretary of the Treasury to spend up to Seven Hundred Billion US Dollars (\$700 billion) to purchase distressed assets (bad assets) from US banks, reduce uncertainty regarding the worth of the remaining assets, and restore confidence in the credit market (Nolen, 2008). On February 12, 2009, the U.S. Congress approved the American Recovery and Reinvestment Act (ARRA) under which President Barack Obama's stimulus package to the tune of $\$ 787$ billion to resuscitate the ailing American economy in the form of tax cuts and direct government spending targeted at working families, seniors, homeowners and the unemployed, and to ensure that home owners maintained their homes which were bought through mortgages (Amadeo, 2020). The German government also proposed 50 billion Euros stimulus package to lift the German economy out of the recession. In April 2009, the "G-20" (the highly industrialised nations of the world) in addition to other regulations voted $\$ 1.1$ trillion to tackle the problem globally. As part of the measures to reduce the 
effects of the global crisis on developing countries, the IMF pledged to increase its concessional lending by 17 billion dollars from the time of the crisis to 2014 (EveryCRSReport.com , November 10, 2008 February 4, 2010).

In Ghana, The Finance Minister, Mr. Ken Ofori-Atta, stated in the 2020 Budget Statement presented to the Parliament of Ghana that the government of Ghana spent about $\$ 11.7$ billion (about GHф64.7 billion) on the banking sector clean up that started in August 2017 as government attempted to save depositors and investors' funds that were locked up in failed financial institutions. Government spent about 1.5 million cedis, to provide relief to depositors when the Bank of Ghana revoked the licenses of 347 microfinance institutions, 15 savings and loans, and 8 finance houses. These were to ensure a well-capitalised, solvent, liquid, profitable, and resilient financial sector to support the economic growth agenda of the government of Ghana. When the banking sector reforms began in August 2017, total assets of the banking sector was GHф89.1 billion for 36 banks. Two years into the reforms, total assets had increased to $\mathrm{GH} \notin 115.2$ billion at the end of August 2019, even with 23 banks. Total deposits improved from $\mathrm{GH} \phi 55.7$ billion to $\mathrm{GH} \notin 76.0$ billion over the same period, reflecting a stronger deposit base, as a result of increased trust and confidence in the banking sector (Ministry of Finance, 2019). Dontoh (2020) reports that the cleanup increased Ghana's debt to about $63 \%$ of gross domestic product by the end of 2019 from $59 \%$ in 2018.

- Fighting pandemics: Today, COVID-19 has brought the economies of the world to their knees. As a result, nations have resorted to lockdowns, closure of national borders, ports and harbours, as well as imposing bans on social and religious gatherings - defying cultural and traditional practices. These actions have crippled the production of goods and services, employment of resources, movements of human beings and goods and services. Governments all over the world are at the forefronts of their nations' fight against the spread of the disease to preserve the lives of their citizens and to bring back economic life. For example, the government of Ghana in addition to other social interventions like supplying food to the needy in societies and reducing electricity and water bills, voted 600 million cedis to support 200,000 businesses and industries that have been hit by the coronavirus pandemic in Ghana at a relatively low interest rate of $3 \%$ to power their operations so as to contribute effectively to economic recovery and growth (Boney \& Andoh, 2020). The Central Bank of Ghana has taken measures to mitigate the negative impact of the outbreak by cutting back on interest rates and reserve requirements, and decreasing banks' 
conservation buffers. The Policy Tracker (2020) of the IMF reports that the government of Ghana committed US\$100 million to support preparedness and response, and about US $\$ 210$ million under its Coronavirus Alleviation Programme to the promotion of selected industries (e.g., pharmaceutical sector supplying COVID-19 drugs and equipment).

Again, on March 27, 2020, the German Parliament adopted various legislative amendments towards the implementation of the COVID-19 Governmental Protective Shield. This led to the setting up of Economy Stabilization Fund (ESF) equipped with $€ 600$ billion to be disbursed as follows: about $€ 400$ billion for public guarantees to secure credits issued by local banks; about $€ 100$ billion for recapitalization measures by way of participation in subordinated debt instruments, hybrid bonds, silent partnerships, convertible bonds and even through direct equity investments; and about $€ 100$ billion for refinancing of special programmes issued by the German Development Loan Corporation. The German government on the same date established an emergency liquidity programme for small companies, self-employed professionals, freelancers and farmers with a total volume of $€ 50$ billion under which the small companies with up to ten employees can receive up to $€ 15,000$ as one-time non-repayable grant to cover the operating costs (Pappalardo, Russo, Stamm, Rumohr, and Keller, 2020).

The Policy Tracker (2020) reports some of the key policy responses to COVID-19 in the United States of America as of April 30, 2020. Among the policies were: US $\$ 484$ billion Paycheck Protection Program and Health Care Enhancement Act which were to be disbursed as follows: US $\$ 310$ billion for additional forgivable Small Business Administration loans and guarantees to help small businesses that retain workers; US $\$ 60$ billion to provide Small Business Administration grants to assist small businesses; US $\$ 75$ billion for hospitals; and US\$25 billion for expanding virus testing. Again, an estimated US $\$ 2.3$ trillion Coronavirus Aid, Relief and Economy Security Act ("CARES Act") which includes: US\$250 billion to provide one-time tax rebates to individuals; US $\$ 250$ billion to expand unemployment benefits, US $\$ 24$ billion to provide a food safety net for the most vulnerable; US $\$ 510$ billion to prevent corporate bankruptcy by providing loans, guarantees, and backstopping Federal Reserve 13(3) programme; US359 billion in forgivable Small Business Administration loans and guarantees to help small businesses that retain workers; US $\$ 100$ billion for hospitals, US $\$ 150$ billion in transfers to state and local governments and US $\$ 49.9$ billion for international assistance including SDR28 billion for the IMF's New Arrangement to borrow. 


\subsection{Conclusions and Recommendations \\ 5.1.1 Conclusions}

The private sector is opined to be the engine of inclusive sustainable economic growth and development, because in comparison with the state, it creates more job opportunities, it increases trade, it produces more goods and services for the citizenry, and generates more tax revenue for governments to finance basic public infrastructure. Exclusively, governments directly produce goods and services for domestic and foreign users, provide law and order, define property rights, embark on large scale infrastructural development, formulate, and implement credible national policies, address financial sector instabilities and crises, markets failures, manage economic recessions and global pandemics through offering of stimulus packages to private sector enterprises and individuals. Governments provide the necessary lubrication, drive, spark, and stimuli to propel private sector growth and the growth of the economy. Creating the ideal environment for the private domestic and international sectors to invest and thrive is crucial for economic growth and development.

Governments co-ordinate and contribute to the development of the economic, political, technological, legal, competitive, social, and cultural environments of their economies. To summarise, the growth and success of the private sector hinges on an efficient public sector. Considering these, the failure of governments in playing their expected critical roles in their respective countries results in economic doom. In spite of the disagreements among development economists, policymakers, researchers, academics, and citizens concerning which economic agent holds the key to the engine of inclusive economic growth and development, it is revealing that whether in normal economic life or economic crisis, developed, underdeveloped or developing nation, capitalist, socialist, or mixed economies, the crucial role of an efficiently functioning state in holding an economy together cannot be overemphasized and for this reason, the state must be seen as the engine of inclusive sustainable growth and development. Figure 2 provides the summary of the model that has guided this study. It summarises the goals or rationale for the study, the questions that needed to be answered, the conceptual framework, the method adopted for the study, the validity of the methodology used and the main result of the study.

\subsubsection{Recommendations}

It is recommended that the roles of the state and the private sector in promoting inclusive sustainable economic growth and development must not be mutually exclusive.

Every economy must seek to provide the precise balance between private sector and state planning that will lead to inclusive sustainable 
economic growth and development. There must be enough public-private partnerships in the execution of critical projects in critical sectors of every economy to ensure efficient and maximum use of resources to better the lot of the people. .

Governments must promote good governance and corruption must be tackled in both the private and public sectors of every economy. 


\section{Figure 2: Summary of the Model for the Study}

\section{GOALS/RATIONALE}

- To determine whether the roles of the private sector and the state in inclusive sustainable economic growth and development are affected by the level of economic development of a country, and by national and global conditions.

- To find out whether the state has any role to play in inclusive sustainable economic growth and development all.

- To highlight some of the exclusive roles of the state in inclusive sustainable economic growth and development.

- To point out the need for governments to be more efficient and proactive in spearheading economic growth and development.

- To elucidate the arguments surrounding whether the private sector or the state is the engine of inclusive sustainable economic growth and development.

- To encourage further research in the area.

\section{RESEARCH QUESTIONS}

- Are the roles of the private sector and the state in inclusive sustainable economic growth and development affected by the level of economic development of a country, and by national and global conditions?

- Does the state have any role to play in economic activities at all?

- What are some of the exclusive roles of the state in inclusive sustainable economic growth and development?

- Is there any need for governments to be more efficient and proactive in spearheading economic growth and development?

- Which sector of the economy (the private sector or the state) is the engine of inclusive sustainable economic growth and development?

\section{CONCEPTUAL FRAMEWORK}

- Government as a lubricator, driver, sparker, stimulator, and coordinator of the private sector and economic activities.

- Interrelated roles of the primary, secondary, and tertiary sectors of an economy.

- Private sector as an embodiment of primary, secondary, and tertiary sector private activities.

- Governments spearheading economic activities for inclusive sustainable economic growth and development. 


\section{METHODOLOGICAL ISSUES}

- Qualitative/Conceptual Analysis

- Exploration of theoretical and empirical literature.

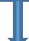

\section{VALIDITY}

Compared with existing theories, empirical studies, and public views.

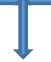

\section{RESULT}

The state as an engine of inclusive sustainable economic growth and development

Source: Researcher's Own Construct, 2020 


\section{References:}

1. Acquah-Sam, E. (2019, Monday, April, 29). Industrialising Ghana: The solution to Ghana's economic problems? Business and Financial Times, Ghana, pp. 9 \& 18 or

https://thebftonline.com/2019/features/industrialising-ghana-thesolution-to-ghanas-economic-problems/

2. African Development Bank Group (2011). Private sector development as an engine of Africa's economic development. African Development Report 2011. Retrieved on $2^{\text {nd }}$ July, 2020 from https://www.afdb.org/fileadmin/uploads/afdb/Documents/Publication s/African\%20Development\%20Report\%202011\%20$\%$ 20Chapter\%201-

The $\% 20$ Role $\% 20$ of $\% 20$ the $\% 20$ Private $\% 20$ Sector $\% 20 \mathrm{in} \% 20$ Africa $\%$ E2\%80\%99s\%20Economic\%20Development.pdf.

3. Allison, D., Dewa. P. and LeBlanc, D. (2012, p.19). Driving Inclusive Economic Growth:The role of the private sector in international development: Report of the standing committee on foreign affairs and international development. The House of Commons, Canada. Retrieved on $26^{\text {th }}$ June, 2020 from https://www.enterprisedevelopment.org/wpontent/uploads/Driving_Inclusive_Economic_Growth.pdf

4. Alinska, A., Filipiak, Z. B., \& Kosztowniak, A. (2018). The importance of the public sector in

5. sustainable development in Poland. Sustainability, 10, 3278; doi: $10.3390 / \mathrm{su} 10093278$

6. Amadeo, K. (March 3, 2020). Obama's stimulus package and how well it worked.

https://www.thebalance.com/what-was-obama-s-stimulus-package3305625 .

7. Berhane, E. (2012). The role of government in East Asian Development: Lessons for Ethiopia.

8. Jonkoping International Business School, Jonkoping University. Retrieved on $17^{\text {th }}$ July, 2020 from https://www.divaportal.org/smash/get/diva2:552095/FULLTEXT01.pdf

9. Boney, E. \& Andoh, D. (2020, Friday, May 1). Stimulus for 200,000 businesses: GH 6000 million to power operations. Daily Graphic, pp. $1 \& 2$.

10. Dearden, N. (2020). The free market will only deepen the coronavirus crisis. Opinion/Health: AljazeerA. Retrieved on $1^{\text {st }}$ July, 2020 from https://www.aljazeera.com/indepth/opinion/free-market-deepencoronavirus-crisis-200408122743522.html 
11. Dontoh, E. (2020). Ghana banking cleanup cost risks surging to $\$ 3.5$ billion. Bloomberg. Retrieved on 7th May, 2020 from https://www.bloomberg.com/news/articles/2020-01-17/ghanafinance- sector-cleanup-cost-risks-surging-to-3-5-billion.

12. IEDC (2020). Economic development reference guide. Retrieved on $29^{\text {th }}$ June, 2020 from

http://www.iedconline.org/clientuploads/Downloads/IEDC_ED_Refe rence_Guide.pdf.

13. Encyclopaedia Britannica (2020). Capitalism. Retrieved on $22^{\text {nd }}$ July, 2020 from https://www.britannica.com/topic/capitalism

14. Encyclopaedia Britannica, Inc. (2020). The neoclassical counterrevolution. Retrieved on $2^{\text {nd }}$ June, 2020 from https://www.britannica.com/topic/development-theory/Theneoclassical-counterrevolution.

15. EveryCRSReport.com (November 10, 2008 - February 4, 2010). The global financial crisis: Analysis and policy implications. Retrieved on $12^{\text {th }}$ June, 2020 from

https://www.everycrsreport.com/reports/RL34742.html

16. Greenspan, A. (2009, Thursday, September 10). Financial crisis will happen again. Daily Graphic, p.2.

17. Hugo Rodriguez (2019). Engines of economic growth: The role of the private sector in international development. Deputy Assistant Secretary for Central America Bureau of Western Hemisphere Affairs. Retrieved on $9^{\text {th }}$ June, 2020 from https://www.state.gov/engines-of-economic-growth-the-role-of-theprivate-sector-in-international-development/

18. IEDC (2000). Economic development reference guide. The International Economic Development Council. http://www.iedconline.org/clientuploads/downloads/iedc_ed_referenc e_guide.pdf.

19. IMFSurvey Magazine (Sept.5, 2009). Rising unemployment marks crisis third wave, says IMF Chief. Retrieved on September, 5, 2009 from

$h$ tps://www.imf.org/external/pubs/ft/survey/so/2009/NEW090509A.h tm.

20. Investopedia (2015). What macroeconomic problems do policy makers most commonly face? Retrieved on $1^{\text {st }}$ July, 2020 from https://www.investopedia.com/ask/answers/020315/whatmacroeconomic-problems-do-policy-makers-most-commonlyface.asp.

21. Kole-Dery, S. (2020, Monday, July 6). Government injects \& 269m. Daily Graphic. pp.1\&3. 
22. Mensah, J. \& Casadevall, R. S. [reviewing editor, 2019, p.1]. Sustainable development: Meaning, history, principles, pillars, and implications for human action: Literature review. Cogent Social Sciences, 5:1, 1653531, retrieved on $25^{\text {th }}$ June, 2020 from https://doi.org/10.1080/23311886.2019.1653531

23. Ministry of Finance (2019). Consolidating the gains for growth, jobs \& prosperity for all. 2020 Budget Statement \& Economic Policy of the Government Of Ghana Presented To Parliament On Wednesday, 13th November 2019 by Ken Ofori-Atta, Minister for Finance, on the authority of His Excellency Nana Addo Dankwa Akufo-Addo, President of the Republic of Ghana.

24. Mohammed, S., Bukari, F., Issahaku, M., \& Mohammed, A. (2019). Assessment of the livelihood empowerment against poverty programme in Karaga District, Ghana. Development in Practice, 29:4, 437-447, DOI: 10.1080/09614524.2018.1551859.

25. Nolen, L. J. (2008). Emergency Economic Stabilization Act of 2008, United States Legislation. Encyclopædia Britannica. Retrieved on 6th May, 2020 from https://www.britannica.com/topic/EmergencyEconomic-Stabilization-Act-of-2008.

26. Odeleye, O. A. (2017). Curbing materialism will reduce social vices, African leaders told. University of Ilorin (n.d.). Retrieved on $2^{\text {nd }}$ June, 2020 from

https://www.unilorin.edu.ng/index.php/fnews/6193-curbingmaterialism-will-reduce-social-vices-african-leaders-told.

27. Office of Fair Trading (2009). Government in markets: Why competition matters - a guide for policy makers. Retrieved on $1^{\text {st }} \mathrm{July}$, 2020 from

https://assets.publishing.service.gov.uk/government/uploads/system/u ploads/attachment_data/file/284451/OFT1113.pdf.

28. Pappalardo, G. F., Russo, G., Stamm, H., Rumohr, v. K., and Keller, J (2020). COVID-19

29. Coronavirus: German government stimulus package for private equity and venture capital-financed companies. Dechert LLT. Retrieved on 6th May, 2020 from https://iclg.com/briefing/11570-covid-19coronavirus-german-government-stimulus-package-for-privateequity-and-venture-capital-financed-companies.

30. Peterson, H. W. (1984). An outline of the American economy. North Carolina: Buries Creak.

31. Policy Tracker (2020). Policy responses to COVID-19. International Monetary Fund. Retrieved on $6^{\text {th }}$ May, 2020 from https://www.imf.org/en/Topics/imf-and-covid19/Policy-Responsesto-COVID-19\#U. 
32. Reed, R. (2015). Here are five ways governments can intervene in the market to create affordable housing. CityMetric. Retrieved on $1^{\text {st }} \mathrm{July}$, 2020 from

https://www.citymetric.com/politics/here-are-five-waysgovernments-can-intervene-market-create-affordable-housing-1173.

33. Samuels, C. B. \& Djigma, A. P. (2016). Initiatives to mobilize the private sector for development: implementation of FfD for results $S D G$, climate-change, and inclusive economic growth. Business sector steering committee. Third international conference for financing for development. New York. Retrieved on 30 ${ }^{\text {th }}$ June, 2020 from https://www.un.org/esa/ffd/wp-content/uploads/2016/04/FfD-SideEvent_-Initiatives-to-Mobilize-the-Private-Sector-forDevelopment.20-April-2016-10AM-1PM.pdf

34. Screpanti, E. \& Zamagni, S. (2005, pp.245). An outline of the history of economic thought. $2^{\text {nd }}$ edition revised and expanded. Oxford New York: Oxford University Press Inc. sdgfund.org (n.d.). Inclusive economic growth for poverty eradication. Retrieved on $22^{\text {nd }} \mathrm{July}, 2020$ from

https://www.sdgfund.org/thematic-area/inclusive-economic-growthpoverty-eradication.

35. Spicer, M. \& Bousquet, F. (2019). The private sector-an engine for growth and stability in fragile countries. Development for Peace, World Bank. Retrieved on $30^{\text {th }}$ June, 2020 from https://blogs.worldbank.org/dev4peace/private-sector-engine-growthand-stability-fragile-countries

36. Stiglitz, J. E. \& Rosengard, K. J. (2015). Economics of the public sector. New York: W. W. Norton \& Company, Inc.

37. Strauss-Kahn, D. (2009). Resources for the future seminar. Washington DC in September 17, 2009; The Business and Financial Times, Monday, September 21, 2009, page 1.

38. Tanzi, V. (1997:p7, 8). The changing role of the state in the economy: A historical perspective IMF Working Paper No. 97/114. Retrieved on $30^{\text {th }}$ June, 2020 from https://www.imf.org/external/pubs/ft/wp/wp97114.pdf

39. The global economic collapse's long-term impacts on developing countries. Statement by Mr. Sha Zukang, Under-Secretary-General for Economic and Social Affairs to the International Monetary and Financial Committee Istanbul, 4 October 2009. Retrieved on 6th May, 2020 from

https://www.un.org/en/development/desa/usg/statements/uncategoriz ed/2009/10/statement-to-the-international-monetary-and-financialcommittee-2.html. 
40. The World Bank (2004). World Development Report 2005: A better investment climate for everyone. The International Bank for Reconstruction and Development/The World Bank. Washington, DC: Oxford University Press, p. 1.

41. Torado, P. M., \& Smith, C. S. (2006). Economic development. $9^{\text {th }}$ ed., Essex: Pearson

42. UK aid (2011). The engine of development: The private sector and prosperity for poor people. Department for International Development (DFID). Retrieved on $9^{\text {th }}$ June, 2020 from https://assets.publishing.service.gov.uk/government/uploads/system/u ploads/attachment_data/file/67490/Private-sector-approach-paperMay2011.pdf.

43. United Nations Development Programme (UNDP, 2017). UNDP'S strategy for inclusive and sustainable growth. New York. Page 4.

44. Utterwulghe, S. (2014). Fostering private sector development in fragile states: A piece of cake? World Bank Blocks. Retrieved on $29^{\text {th }}$ June, 2020 from https://blogs.worldbank.org/psd/fostering-privatesector-development-fragile-states-piece-cake. 